\title{
Single Mothers and Incentives to Work: The French Experience
}

\author{
Libertad Gonzalez ** \\ Universitat Pompeu Fabra
}

March 10, 2005

\begin{abstract}
This paper analyzes the effect of the 1998 reform of the French single parents allowance on the labor supply of single mothers with very young children. The reform aimed at encouraging participation by allowing eligible single parents to accumulate benefits and labor earnings for a limited period of time. Using data from the French Employment Survey, the analysis shows that single mothers affected by the reform had experienced a significant increase in their employment rate four years after the reform was implemented. During the same period, the employment rate of married mothers with young children did not experience a significant change, suggesting that at least part of the increase was a consequence of the reform. These results provide some evidence that benefit schedules that provide financial incentives to work can have significant effects in getting single moms back to work, even in the presence of very young children.
\end{abstract}

Keywords: Single mothers, labor supply, welfare benefits.

JEL Codes: I38, J21, H53.

\footnotetext{
- Email at: libertad.gonzalez@upf.edu. Mailing address: Universitat Pompeu Fabra, Departamento de Economía y Empresa, Ramón Trias Fargas, 25-27, 08005 Barcelona, Spain. Phone: (34) 935422610. Fax: (34) 935421746.

* I thank CREST for the use of their facilities during the winter of 2004, and participants at the centrA seminar in Seville for their comments. All remaining errors are mine.
} 


\section{Introduction}

Single mother families have received a great deal of attention from researchers and policy makers in recent years. This is partly attributable to the large increases in the prevalence of this type of family that have taken place in some Western countries during the past few decades. Some of the questions raised by the increasing prevalence of this non-traditional family type regard the conflicting role of women as mothers and breadwinners.

Western countries differ greatly in the extent to which single mothers participate in the labor market. In the mid-1990s, 27 percent of single mothers in the United Kingdom reported working at least 10 hours a week, compared with 76 percent in the United States and 72 percent in France. ${ }^{1}$ Single mothers out of work are more likely to be poor and dependent on public support. On the other hand, the effects of maternal employment on children are still not well understood. Higher income in the household is associated with positive outcomes for children, ${ }^{2}$ but lack of maternal care and parental supervision is thought to affect children and adolescents negatively. ${ }^{3}$ In any case, understanding what drives the labor supply decisions of single mothers under different environments would help inform policies aimed at preventing and alleviating poverty for these particularly vulnerable families.

This paper looks into the effects of benefit systems on the labor supply of single mothers by analyzing the effect of a reform of the French single parents allowance that was meant to encourage single mothers with very young children to work by introducing a temporary earnings top-up schedule.

\footnotetext{
${ }^{1}$ Estimates from Luxembourg Income Study data, Wave IV.

${ }^{2}$ See Duncan and Brooks-Gunn (1997), Mayer (1997), McLoyd (1998).

${ }^{3}$ The literature on the effects of maternal employment on children is mixed. Some have found negative effects of maternal employment when children are young (Ruhm 2004, Harvey 1999). Others find that maternal employment has positive effects on children in low-income families (Moore et al. 1996, Zaslow and Emig 1997).
} 
Other previous studies that have looked into the effect of taxes and benefits on the labor supply of single mothers have focused on the US (Meyer and Rosembaum 2000, 2001, Eissa et al. 2004) and the UK (Gregg and Harkness 2003, Ermish and Wright 1991, Jenkins 1992). The expansions of the EITC in the US have been shown to induce more single mothers to join the labor market, suggesting that single mothers' employment rates are responsive to financial incentives. ${ }^{4}$ However, this is a very different program from the one we are considering in that it is strictly an earnings supplement, so that a woman is eligible only if she works, as opposed to the French single parents allowance, which guarantees a minimum level of income independently of employment status. Other studies have analyzed the effect of welfare reform in the 1990's on the labor supply of single mothers in the US and the UK, but the large number of reforms going on at the same time makes it hard to identify the effect of specific policy changes. ${ }^{5}$

The effect of financial incentives on the labor supply of married mothers has received some attention in France in recent years, particularly following a reform in family policy in 1994 that was meant to encourage mothers to stop working after the birth of their second child. The reform was followed by a sharp decline in activity and employment for eligible married mothers (Afsa 1996, Piketty 1998, 2002). Little attention has been paid, however, to single mother families, who were not affected by that reform. Other related work has evaluated the financial incentives to work created by the French minimum income guarantee (RMI). Gurgand and Margolis (2001, 2005) show that the gains from employment are low for single mother families compared with non-employment and RMI recipiency. Piketty (1998) also suggests that the introduction of the RMI in 1988 instituted significant disincentives to work for single mothers.

\footnotetext{
${ }_{5}^{4}$ See, for instance, Meyer and Rosenbaum (2001).

${ }^{5}$ See, for instance, Gregg and Harkness (2003), who find that the employment of single mothers rose by 5 percentage points over a 10 year period as a result of the reforms.
} 
There is thus some evidence that financial incentives can successfully induce mothers of very young children to leave the labor force. This paper analyses how successfully financial incentives can be used to encourage single moms to return to paid employment.

France experienced a pronounced increase in the prevalence of single mother families in recent years. The number of single mother families as a proportion of all families with children rose from $9.6 \%$ in 1990 to $13.8 \%$ in $2002 .{ }^{6}$ According to a recent study (CERC 2004), children in single mother households in France are much more likely to be poor than those in two parent families. In 2000 , almost $15 \%$ of children living with a single mother were poor, compared with less than $8 \%$ of all children.

Most of French single mothers participate in the labor market. In 1994, 86 percent of single mothers were either working or looking for a job in France. Activity rates of French single mothers are amongst the highest in Europe. However, during the high unemployment period in the late 1990's, activity and employment rates fell significantly. In 1999, 63.7 percent of single mothers were working, compared with 70.3 percent in 1993 . The trend may have started to reverse since then.

Single mothers in France are entitled to several different allowances, depending on the size of the family, the ages of the children, and the level of income. The French single parents allowance (Allocation de Parent Isolé or API) guarantees single mothers with at least one child under the age of 3 a minimum income level. In 2003, an eligible single mother with two children was entitled to a monthly allowance of 870 euros if she received no other income. Up until January 1999, labor income was taxed at 100\%, i.e., an extra euro of earnings was accompanied by a reduction of one euro in the allowance received.

\footnotetext{
${ }^{6}$ Estimates from the French Employment Survey.
} 
The single parents allowance was reformed in 1998 to allow women to accumulate labor earnings with full perception of the allowance for a limited period of time. From January 1999 on, a woman on API who started working for pay could keep the full API amount on top of her earnings for up to 6 months, and then for 9 extra months labor earnings would be taxed at 50\%. A single mother with two children who started working at the minimum wage before the reform would make around 13,000 euros in the first year (in 2003 euros), which would raise her above the income guaranteed by the API, thus she would not receive any allowance. After the reform, she would receive an extra 7,160 euros of API during that first year of work, thus increasing her income by 55 percent.

The longitudinal nature of the data allows us to compare the evolution of employment rates for single mothers affected by the reform with that of other mothers of similar characteristics. The analysis shows that the reform was followed by a significant increase in employment rates for single mothers affected by the reform. This increase was significantly higher than the change experienced by married mothers with very young children. The increase in employment rates seemed to take place through a rise in full time work, and it was driven by young, low-educated single mothers. The effect appeared to persist four years after the reform.

The rest of the paper is organized as follows. Section 2 describes the evolution of the activity and employment rates of single mothers in France since 1990, and provides a short description of the French benefit system, focusing on the provisions that are more relevant to single mother families. The following section describes the data and the main variables, and introduces the methodology. I use data from the French Employment Survey from 1995 to 2002 . Section 4 reports the results of estimating the 
effect of the 1998 reform on the employment and activity rates of single mothers, and section 5 concludes.

\section{Single Mothers and Work in France}

\subsection{Employment and Participation Rates}

Figure 1 shows employment and activity rates for all women and single mothers (aged 18 to 55) in France, from 1990 to 2002. Single mothers were more likely to participate and more likely to be employed than other women during the whole period. ${ }^{7}$ In the first half of the 1990s, between 67 and 70 percent of single mothers reported being employed (versus 58 to 60 percent of all women). However, employment rates declined steadily for single mothers from 1993 to 1999 . The 70.3 percent employment rate of 1993 had become 63.7 percent in 1999.

A similar trend can be observed for activity rates. In 1994, 86.2 percent of single mothers were working or looking for a job, compared with only 80.5 in 2001 . After 1999, the employment rate of single mothers seemed to increase until the end of the period. Activity rates also seemed to pick up in 2002. Note that the $1994-98$ period coincided with high unemployment rates in France (around 12 percent), which declined significantly after 1998 (reaching less than 9 percent in 2001).

\subsection{The French Benefit System and Incentives to Work}

The French "single parent allowance" (API) was created in 1976 to provide support for single parents while they had at least one child younger than 3 years of age or right after a separation or divorce. Thus a single mother can receive the allowance for as long as

\footnotetext{
${ }^{7}$ This is not the case in other countries. For a study of the determinants of participation of single mothers across countries, see Gonzalez (2004).
} 
three years. ${ }^{8}$ It is a means-tested allowance, so that the amount received is the difference between the "guaranteed" income level and other income in the household (including other allowances). Labor earnings are thus taxed at 100\%. The guaranteed amount varies with the number of children. In 2003, the guaranteed monthly amount for a single mother with one child was 695 euros, plus 174 per additional child. ${ }^{9}$

The API was reformed in 1998 (Law 98-657) with the explicit goal of encouraging participation. A single mother on API could, starting January 1999, start working and accumulate labor earnings and the whole API amount for 3 to 6 months. ${ }^{10}$ After that initial period, labor earnings would be taxed at 50\% during the 9 following months. Following this period, labor earnings would be taxed at $100 \%$, just like they were before the reform. Thus the reform increases effective wage for as long as 15 months. ${ }^{11}$

The law 98-657, whose explicit goal was to fight "exclusions", included other measures intended to improve the employability of vulnerable segments of the population, such as the young, the old, the long-term unemployed, and welfare recipients. These included personalized measures of orientation and training and some incentives for employers who hired workers in those groups at risk of exclusion.

There are of course other benefits apart from the API that may be available to single mothers in certain situations. All families with at least 2 children under 18 years of age in France are eligible for a universal family benefit, which varies with number and age of the children. In 2003, a family with 2 children under 11 received 111 euros a month. Families with at least 3 children over 3 years of age were also eligible for a meanstested "income supplement" (145 euros a month in 2003). There is also a means-tested

\footnotetext{
${ }^{8}$ The time limit is 12 months if the youngest child is older than 3 .

${ }^{9}$ In 2003, minimum wage for a full-time job was 1,090 euros.

${ }^{10}$ The API amount that a family receives is evaluated every three months. The duration of the period during which labor earnings do not reduce the allowance received depends on the exact timing of the woman's activity with respect to the quarterly evaluations.

${ }^{11}$ In fact, under some conditions, if a single mother loses her job after that period, she can qualify again for the earnings top-up once she finds another job.
} 
housing allowance that helps pay for rent. Finally, the minimum income guarantee (RMI), introduced in 1988, is a means-tested benefit that guarantees a minimum level of income, as a function of the composition of the household. Its amount is considerably lower than that of API. ${ }^{12}$ The amount of these other benefits has not changed significantly in real terms during the 1990-2002 period. However, it is important to take them into account when evaluating the effect of the API on the employment rates of single mothers.

Since the 1998 API reform increased expected income if working for pay while not affecting income if a single mother does not work, in a static framework the expected effect of the reform is to increase participation and employment amongst eligible single mothers. ${ }^{13}$ From a more dynamic point of view, the effect of the reform is equivalent to an anticipated wage increase. The literature on intertemporal labor supply suggests that an anticipated wage shock would result in an increase in labor supply, since it would generate only a substitution effect. ${ }^{14}$ This contrasts with the effect of a permanent or unanticipated wage shock, which would result in conflicting income and substitution effect that may cancel each other out.

In order to illustrate the financial incentives to work created by the benefit system, it will be useful to compare the benefits to which a single mother is entitled if she does not work for pay versus expected benefits in the employment scenario, both before and after the reform.

The level of benefits is essentially a function of the number of children, their ages, and other income. For simplicity, let us assume that there is no other income in the

\footnotetext{
${ }^{12}$ There are other benefits available to families with children, but their relevance for single mother families is extremely limited (APE, APJE, etc). There are also the parental leave and child care provisions, which did not change significantly during the period.

${ }^{13}$ Although the effect on hours for those already working is uncertain, due to conflicting income and substitution effects in the intensive margin.

${ }^{14}$ See, for instance, Cahuc and Zylberberg (2004), pages 19-27. See also Card (1994) for a critical assessment of the intertemporal labor supply model.
} 
household apart from the mother's labor earnings and benefits. Thus, if a woman is not working, the level of benefits depends only on the number of children and their ages. If there are children under the age of 3 , the woman is entitled to the API. ${ }^{15}$ If they are all over 3, she can still qualify for the RMI. The guaranteed monthly amounts as a function of the number of children, in 1997 francs, can be found in Table 1. I show the RMI guarantee as well as the API for the sake of comparison, as many single mothers not eligible for API are on RMI. ${ }^{16}$ A single mother with 2 children would be entitled to 5,271 francs a month if at least one of her children was under 3 years of age (the API guarantee), and 4,325 otherwise (the RMI guarantee).

The next step is to calculate benefit entitlement if working. But benefits are a function of earnings. Thus I show benefit entitlement for different earnings levels. In 1997 francs, average monthly earnings for working single mothers were 7,490 francs. ${ }^{17}$ The median was $6,476 .{ }^{18}$

\section{a) Benefits if working, before the reform}

Benefit entitlement is calculated at 5 different levels of earnings. ${ }^{19}$ Now the benefits include not only API or RMI, but also the universal family benefit and the family supplement, in those cases in which the family qualifies and is not eligible for API/RMI (or its amount is lower than the family allowances). Table 2a) shows benefit levels for a single mother with children under 3 who starts working, for five different levels of earnings. Note that, before the reform, and except for the lowest earnings category, a single mom who started working would be above the API guarantee, and therefore would be eligible only for the universal family benefit.

\footnotetext{
${ }^{15}$ She is also eligible for the RMI, but its guaranteed amount is lower.

${ }^{16}$ The tables shows the API guarantee and the RMI guarantee. Other allowances received must be subtracted from the API/RMI amount so that the level of benefits received would not change.

${ }^{17}$ The minimum wage for a full-time job in 1997 was 6,664 francs.

${ }^{18}$ Percentile 25 was 4,867 francs; percentile 75 was 8,548 francs.

19 3,000 francs a month, 5,000, 6,664 (the minimum wage for a full time job), 8,000 and 10,000.
} 
A simple comparison between tables 1 and 2a) shows that benefit entitlement is considerably reduced when working. A single mother with 2 children, at least one under 3 years of age, working at the minimum wage, would be entitled to 675 francs a month in benefits, versus 5,271 if she was not working.

The RMI recipients could benefit from an earnings top-up program (intéressement), which allowed for partial accumulation of earnings and benefits during the first 750 hours of work..$^{20}$ Table 3a) shows benefit entitlement during the first year of work, for different earnings levels, in 1997 francs. Note that benefit levels if working are higher for RMI recipients than for API recipients in some cases. For single mothers with at least 3 children this is due to the family supplement, only available to families with 3 or more children, all over the age of 3 . For families with less than 3 children, this is attributable to the earnings top-up program. ${ }^{21}$ In our sample, 3.7 percent of single mothers eligible for API were in fact receiving RMI during the 1995-1998 period (versus 15.5 percent of single mothers not eligible for API).

\section{b) Benefits if working, after the reform}

In 1998 the API allowance was reformed to allow women to accumulate labor earnings with full perception of the allowance. From January 1999 on, a woman on API who started working for pay could keep the full API amount on top of her earnings for up to 6 months, and then for 9 extra months earnings would be taxed at 50\%. After that initial period, earnings would be taxed at $100 \%$. The reform did not affect the guaranteed amounts, thus benefits if not working remained unchanged. The change in benefit eligibility during the first year of work, by earnings level, can be seen in table $2 b$ ).

\footnotetext{
${ }^{20}$ Before 1999, an RMI recipient who started working could subtract only $50 \%$ of her earnings from the RMI guarantee for the first 750 hours of work (about 5 months).

${ }^{21}$ Note, however, that in order to benefit from the RMI earnings top-up program one had to be on RMI before taking up employment, thus being subject to the lower guaranteed amount.
} 
After January 1999, a single mother with 2 children (at least one of them under 3) who started working at the minimum wage would expect to receive (still in 1997 francs) 3,605 francs a month during the first year of work, ${ }^{22}$ compared with just 675 before the reform. This represents a 40 percent increase in expected income if working. The percent increase in income after the reform varies with earnings and number of children. For women working at the minimum wage, the increase ranges from 35 to 40 percent depending on the number of children, while its size is between 11 and 18 percent for wages around 10,000 francs a month.

What happened with single mothers not eligible for API? As mentioned, the RMI already allowed for partially accumulating labor earnings with benefits for a certain amount of time. ${ }^{23}$ The new rules for the API also applied to the RMI starting in January $1999,{ }^{24}$ so that a single mother with 2 children (all of them older than 3 ) who started working at the minimum wage would expect to receive (in 1997 euros) 2,659 euros a month during the first year, ${ }^{25}$ compared with 808 before the reform (see table $3 \mathrm{~b}$ ). This represents a 25 percent increase in expected income if working. The percent increase now ranges from 14 to 27 percent for women working at the minimum wage.

In sum, after January 1999, benefits if not working remained unchanged for all single mothers, while benefits if working increased for the first year of work, ${ }^{26}$ and this increase was more pronounced for single mothers eligible for API. Table 4 shows the increase in (monthly) benefits during the first year of work, for single mothers eligible versus not eligible for the API, working at the minimum wage, in 1997 francs. A single mother with 3 children, at least one of them under 3, experienced an increase of 3,120

\footnotetext{
${ }^{22}$ Calculated as benefits during the first 12 months divided by 12 months.

${ }^{23}$ See footnote 20 .

${ }^{24}$ I.e., possibility of perceiving the whole benefit amount for the first 3 to 6 months of work, then $50 \%$ of earnings subtracted from the guaranteed amount for 9 more months.

${ }^{25}$ Again, calculated as benefits during the first 12 months divided by 12 months.

${ }^{26}$ More precisely, for the first 12 to 15 months.
} 
francs a month after the reform, compared with a 1,435 increase for single mothers not eligible for API after the reform.

In 2002 euros, single mothers eligible for API experienced an increase in expected benefits during the first year of work (if working at the minimum wage) that was between 1,410 and 3,820 euros higher (depending on the number of children) than the increase experienced by single mothers not eligible for API. The increase in benefits for RMI recipients was however still sizeable. ${ }^{27}$

Starting 1999, thus, there were stronger financial incentives to work for all single mothers, but especially for those eligible for API. This suggests that, everything else the same, single mothers should be more likely to work after the reform. ${ }^{28}$ Moreover, we expect the increase in the likelihood of working to be higher for those women eligible for API under the new rules, compared with those not eligible.

\section{Data and Methodology}

The data set used in the estimation is the French Employment Survey (Enquête Emploi or EE), years 1990 through 2002. The EE is a nationally representative yearly survey of approximately 75,000 households. Detailed information on household composition and employment status is collected. Each household is interviewed three consecutive years.

The sample is limited to single mother families where the mother is between 18 and 55 years of age. Single mother families are defined as households headed by a female

\footnotetext{
${ }^{27}$ Note that some additional measures were also implemented to improve the employability of welfare recipients (both RMI and API).

${ }^{28}$ Note that, when evaluating the effect of the reform on participation, the increase in benefits should be measured "net" of the fixed costs of working, such as childcare costs. The empirical specification should thus take into account the fact that these fixed costs may vary with characteristics of the household. This issue is discussed in detail in section 3 .
} 
and containing only the mother and her dependent children under 18 years of age. ${ }^{29}$ The variables used to identify single mother households are "type of household" and "number of children under 18 ". A woman is characterized as employed, unemployed or inactive following the recoded variable "activity" in the survey. The analysis will focus on the period 1995-2002 (four years before and four years after the reform).

The number of single mothers in the sample is 22,954 . Overall, 65 percent of them are employed. The employment rate is however much lower for single mothers with children under the age of 3 (eligible for API). Only 51 percent of them are active, and their employment rate is 32 percent.

Single mothers who had at least one child under the age of 3 after December 1998 were affected by the reform. The French Employment Survey interviews each household three consecutive years. I thus define the "treated" group as those women who qualified for the new rules in at least one of the three interviews. ${ }^{30}$ The longitudinal nature of the data allows us to observe at least some of these women before the reform took place. Thus we can compare the behavior of the treated group, before and after, with that of a "comparison" group. I define the comparison group as women who were eligible for the single parents allowance at some point during the four pre-reform years, but not after, i.e. they were not affected by the post-reform API rules. ${ }^{31}$ For instance, a single mother whose youngest child turned 3 in December 1998 (and who had no subsequent child) was not affected by the new rules, and thus belongs in the comparison group. A single mother whose child turned 3 in June 1999 would have been eligible for the API under the new rules for 6 months, and thus belongs in the treatment group.

\footnotetext{
${ }^{29}$ Unmarried women with children who live with the grandparents of the children are excluded from the sample since they cannot be identified in the data. Cohabiting couples with children are not counted as single mother families.

${ }^{30}$ I.e., women aged 18 to 55 who were single mothers and had a child under the age of 3 at the time of an interview that took place after January 1999.

${ }^{31}$ I.e., women aged 18 to 55 who were single mothers and had a child under the age of 3 at the time of an interview that took place before January 1999, but not after January 1999.
} 
The following probit model for the probability that a woman $i$ in group $j$ (treatment or comparison) and period $t$ (before or after the reform), is employed (active) is estimated:

$$
P\left(Y_{i j t}=1\right)=\Phi\left(X_{i j t} \beta+\alpha d_{j}+\gamma d_{t}+\lambda d_{j} d_{t}+\varepsilon_{i j t}\right)
$$

Where $Y$ is a dummy that takes value 1 if a single mother is employed (active), $\Phi$ is the normal cumulative distribution function, $X$ is a vector of individual characteristics, $d_{j}$ is a dummy that takes value 1 if the woman belongs to the treatment group, $d_{t}$ is a dummy that indicates the period after the reform, and $d_{j} d_{t}$ is the interaction of the two (taking value 1 for treated single mothers, after the reform). Thus $\alpha$ measures the difference in the pre-reform employment rates of the treatment and the comparison group, $\gamma$ gives us the change in employment for the comparison group after the reform, and $\lambda$ measures the change in employment for the treatment group relative to the comparison group.

In the vector $X$, I include age of the woman, age squared, age cubed, education level, ${ }^{32}$ marital status of the woman, ${ }^{33}$ and a dummy for cities with more than 200,000 inhabitants. Also included are dummies for number of children and dummies for children under 3 and under 6 years of age (the omitted category being no children born). These are meant to capture how the fixed costs of working vary with the number and ages of the children. Childcare costs, for instance, are expected to increase with the number of children and to decrease with their age (childcare is free for children aged 3 or older). For this reason, specifications will also be estimated that allow the effect of the reform to vary with the number of children.

\footnotetext{
${ }^{32}$ Both years of education and dummies for vocational training, high school graduation and university diploma.

${ }^{33}$ Never married, divorced, separated or widowed.
} 
A set of year dummies is also included in the regressions. The omitted years are 1998 (the last year before the reform) and 2002 (four years after), so that $d_{t}$ captures the change in employment four years after the reform with respect to the year before.

For the comparison group to be valid, we need to assume that both groups of single mothers would have followed a similar path over time in the absence of the reform. However, single mothers not eligible for API were still eligible for RMI, which was also reformed in 1998 in order to encourage participation, although to a smaller extent, as we argued in section 2. In our data, 15.5 percent of single mothers not eligible for API were receiving the RMI before $1999 .{ }^{34}$ Thus the differential change in employment between the two groups can only be interpreted as a lower bound on the effect of the API reform.

As an alternative comparison group that is less likely to be affected by the RMI reform, I propose using married mothers with at least one child under the age of 3 at the time of one of the interviews. Only $0.5 \%$ of them were on RMI between 1994 and 1998. ${ }^{35}$ The activity and employment rates of married mothers with children under 3 was, however, higher than for single mothers in the treatment or comparison group. In a period of increasing participation, we expect that the group that starts from a higher employment rate would possibly grow at a slower rate in percentage terms. Thus the increase in employment rates for single mothers affected by the reform, relative to married mothers with very young children, could be interpreted as an upper bound for the true effect of the reform.

\footnotetext{
${ }^{34}$ There was no significant change after 1999 in the number of single mothers who were RMI recipients.

${ }^{35} 0.8 \%$ during the $1999-2002$ period.
} 


\section{Estimating the Effect of the Reform}

\subsection{Descriptive Statistics}

Table 5 shows some descriptive statistics for single mothers in the treatment and comparison groups. There are 1,928 single mothers in the treatment group and 1,587 in the comparison group, while there are 36,018 married mothers in the sample.

Note that single mothers in the comparison and treatment groups are very similar in almost all respects. The employment rate of single mothers who were affected by the reform was 37 percent (their activity rate was 53 percent), compared with 35 percent for the comparison group (and a 57 percent activity rate). Both groups of women are 31 years old on average, they have 13 years of education, about 27 percent have a vocational degree while only 5 to 6 percent have a university degree, almost half of them live in a city, and their distributions of number of children look strikingly similar. ${ }^{36}$ The similarity of both groups of women supports the assumption that they would have behaved similarly in the absence of the reform.

As for married mothers, they are slightly older (32 years old, on average) and more educated than the treatment group. More than 47 percent of married mothers in the sample have a high school degree or some university education, versus only 29 percent of treated single mothers. Married mothers are also more likely to have several kids. Finally, the activity and employment rates or married mothers (62 and 54 percent, respectively) are significantly higher than for the treated group.

\subsection{Baseline Specification}

Table 6 (columns 1 and 2) displays the results from estimating equation 1 with the sample of single mothers. The first specification does not include the year dummies,

\footnotetext{
${ }^{36}$ Note that about 10 percent of single mothers in the sample do not have a child under the age of 6 present. Those observations correspond to interviews that took place before the birth of the child.
} 
while the second one does. The coefficient on $d_{j}$ gives us the difference in employment rates between the treatment and comparison groups before the reform, while $d_{t}$ gives us the change in employment for single moms not affected by the reform. The coefficient on $d_{j} d_{t}$ gives us the difference-in-difference estimate of the change in employment for treated single moms, relative to the comparison group.

Most of the controls are significant at the $99 \%$ confidence level. The age and education variables are strongly significant and have the expected signs. ${ }^{37}$ Older, more educated single mothers are more likely to be employed. More children in the household and younger children are significantly associated with a lower probability of working. Unmarried mothers are less likely to work than divorced or separated mothers. Living in a city is associated with higher employment probabilities. Only two of the year dummies are significant. ${ }^{38}$

The coefficient for treated single mothers $\left(d_{j}\right)$ is negative and significant at the $90 \%$ confidence level, indicating that the treatment group was less likely to be employed than the comparison group before the reform, once we account for differences in characteristics and year effects. The indicator for after the reform $\left(d_{t}\right)$ is positive but not significant, implying that the employment rate of single mothers in the comparison group did not increase significantly after 1998.

The employment rate of single mothers affected by the reform had increased by 7 to 10 percentage points four years after the reform, and this increase was significant. ${ }^{39}$ However, it was not significantly higher than the increase for single mothers not

\footnotetext{
${ }^{37}$ Age cubed, although not shown in the table, is included in the regressions and strongly significant.

${ }^{38}$ The dummy for 1996 is significantly negative at the $90 \%$ confidence level, while the dummy for 1999 is significantly negative at the $95 \%$ confidence level.

${ }^{39}$ The absolute increase in the employment rate of treated single mothers equals the coefficients for $d_{t}$ plus $d_{j} d_{t}$. The sum of both coefficients is significantly positive at the $90 \%$ confidence level in the first specification, and at the $95 \%$ in the second.
} 
affected by the API reform (since $d_{j} d_{t}$ gets positive coefficients, but they are not significant).

The same set of regressions is estimated using activity rather than employment as the dependent variable (columns 3 and 4). ${ }^{40}$ The activity rate of the treatment group was lower than for the comparison group. The increase in the activity rate of single mothers not affected by the reform $\left(d_{t}\right)$ was not significantly different from zero, and treated single mothers did not experience a significant differential increase. Thus, after the reform, activity rates did not increase significantly for either the treatment or the comparison group, while treated single mothers increased their employment rate, but not significantly more than the comparison group.

As mentioned in section 3, the differential increase in employment and activity rates between the two groups of single mothers can only be interpreted as a lower bound for the effect of the API reform, given that the RMI was also reformed at the same time. Thus we propose using married mothers with very young children as an additional comparison group, less likely to be affected by the RMI rules. Equation 1 is then expanded to include two $d_{j}$ dummies, one indicating all single mothers $(j=1)$, and a second dummy for the treated group $(j=2)$. There are now two interaction terms, one indicating single mothers after the reform $\left(d_{j=1} d_{t}\right)$, and the other for treated single mothers after the reform $\left(d_{j=2} d_{t}\right)$. The first interaction term gives us the differential change in employment for single mothers not affected by the API reform relative to married mothers. The second one indicates the change in employment for treated single mothers, relative to single mothers in the comparison group. The results from this specification are presented in table 7.

\footnotetext{
${ }^{40}$ None of the year dummies are significant in the regression for activity rates.
} 
The results show that treated single mothers experienced a significant increase in their employment rates of about 8 percentage points. This increase was significantly higher than the change for married mothers with very young children. ${ }^{41}$ It was also 4 to 6 points higher than the increase for single mothers in the comparison group, but this difference was not significant. As for activity rates, they did not change significantly for the treated group, neither in absolute terms, nor relative to the comparison groups.

In sum, the estimated effect of the API reform, four years after its implementation, was a significant increase in the employment rate of affected single mothers, both in absolute terms and relative to married mothers in the comparison group, while there was no significant increase in activity rates. The size of the increase in the employment rate of treated single mothers was between 9 and 10 percentage points, relative to married mothers with very young children. However, the increase in employment was not significantly higher for the treated group compared with single mothers in the comparison group.

\subsection{Alternative Specifications and Robustness Checks}

Some alternative specifications have been estimated, including separate regressions by education level and by age, some additional interaction terms, and regressions that estimate separately the effect of the reform on part and full time work. ${ }^{42}$ I also estimate specifications that aim at distinguishing between short and long term effects of the reform.

So far it has been assumed that the effect of the reform was common for all single mothers. However, if expected wages differ across women, then the potential effect of

\footnotetext{
${ }^{41}$ The diff-in-diff estimate for the change in the employment rate of treated single mothers relative to married mothers equals the coefficient for $d_{j=2} d_{t}$, plus the one for $d_{j=1} d_{t}$.

${ }^{42}$ Regression results are available upon request.
} 
the reform would differ as well. Take, for example, a single mother who started working after the reform and earned 5,000 francs a month (in 1997 francs). She would enjoy a total income between 50 and $60 \%$ higher (depending on the number of children) than she would have in the absence of the reform, during her first 12 months of work. However, the increase in income attributable to the reform would be between 20 and $21 \%$ for a single mother making 10,000 francs a month (see table 2 ).

It may be reasonable to assume that women with higher educational attainment have higher expected earnings than those with lower education. If this is the case, then we would expect the reform to affect more strongly those women with lower educational attainment (and therefore lower expected wages). In order to verify the differential effects of the reform by education level, Probits are run separately for women with different levels of education (see table 8). The results show that the employment rate of low-educated single mothers affected by the reform increased significantly after 1998 (by about 9 percentage points, relative to married mothers in the comparison group), while this was not the case for more highly educated single moms. ${ }^{43}$

It was mentioned in section 3 that the effect of the reforms might vary with the number of the children because of differences in the fixed costs of working. Thus regressions are estimated that interact the dummies that measure the effect of the reform with the number of children. It turns out that the increase in employment is higher for single mothers with more children. Single mothers affected by the reform with more than two children experienced an increase in employment rates that was significantly higher than the increase for single mothers in the comparison group. This is probably because the pre-reform employment rates were much lower for single mothers with more children.

\footnotetext{
${ }^{43}$ I run the regressions separately for women with and without an university education, and also for women with and without a high school degree.
} 
Additional robustness checks include variations of the regressions that also include interactions between the year dummies and number of children, between the year dummies and presence of a child under the age of 3, and between number of children and presence of children under the age of 3. These are not reported as the baseline specification because the additional interaction terms are not significant. The results seem quite robust to all the different specifications. The Probits are also run separately by age group, showing that most of the effect comes from younger women (aged 45 or less).

We may also wonder whether the effect of the reform took place through increases in part-time versus full-time employment. Thus I run a set of multinomial logits where the dependent variable takes three possible values: out of work, part-time work, and full-time work. ${ }^{44}$ The results suggest that single mothers affected by the reform were significantly more likely to work full-time after the reform (relative to married mothers in the comparison group), while there was no significant differential increase in parttime work.

The baseline specification estimated the effect of the reform, four years after its implementation. We may be interested in knowing more about the specific timing of the effect. Thus I run regressions that include different numbers of post-reform years. In 1999, the first year of implementation, the employment and activity rates of treated single mothers did not increase significantly above single or married mothers in the comparison groups. Two years after the reform, the employment rate of affected single moms had increased significantly in absolute terms, but not relative to the comparison groups. ${ }^{45}$ Three years after, the increase in employment for the treated group was still

\footnotetext{
${ }^{44}$ Regression results are available upon request. I have also run ordered probits for the same outcome variable.

${ }^{45}$ The increase relative to single mothers in the comparison group was 2.4 , while the differential increase relative to married mother was 6.7 points.
} 
not significantly higher than for the comparison groups. ${ }^{46}$ Thus our estimated "upper bound" on the effect of the reform was not significantly higher than zero until the fourth post-reform year, while the "lower bound" is never significant.

\section{Conclusion}

This paper analyzes the effect of the 1998 reform of the French single parents allowance (API) on the labor supply of single mothers. The reform was aimed at encouraging participation, and introduced a temporary earnings top-up schedule that increased income for benefit recipients who took up paid employment.

Using data from the French Employment Survey, I estimate regressions for both employment and activity rates, where the probability that a woman is employed (active) is a function of her personal characteristics, a set of year dummies, and a binary variable indicating the period after the reform was implemented. Dummies are also included for the different "groups" (treated versus comparison), and for the group dummies interacted with the dummy indicating after the reform. The data cover four years before and four years after the reform.

The employment rate of single mothers affected by the reform increased significantly in absolute terms between 1998 and 2002 (by 7 to 10 percentage points). In order to know what fraction of this increase can be attributed to the API reform, we need to know whether this increase was higher than for other women who were not affected by the reform.

A first comparison group is composed of single mothers eligible for API but who were not affected by the reform (either because their youngest child turned 3 or because they entered a new marriage or partnership before January 1999). Single mothers

\footnotetext{
${ }^{46}$ Estimated lower bound of 2.4 points (with respect to other single mothers); estimated upper bound of 7.2 points; none of them are significant.
} 
affected by the reform experienced an increase in employment that was 4 to 6 points higher than the increase experienced by the comparison group four years after the reform, but this difference was not significant. There was also no significant difference in the evolution of activity rates for both groups of single mothers. However, this can only be interpreted as a lower bound on the effect of the API reform, since the same earnings top-up schedule was also introduced in the RMI benefit, quite common among single mothers not eligible for API. Moreover, the law that reformed the API and RMI also promoted active measures to help find employment for welfare recipients (thus including both API and RMI recipients).

Thus a second comparison group is introduced, composed of married mothers with children younger than 3 (less likely to be affected by the RMI reform). It turns out that single mothers affected by the API reform were 3 to 5 points more likely to participate in the labor market for years after the reform, relative to married mothers, while they were about 9 points more likely to work, and the different evolution of the employment rates was significant.

In sum, the analysis suggests that the employment rate of eligible single mothers (those with children under age 3) had increased significantly four years after the reform. This increase was significant relative to married mothers in the comparison group. However, it was not significant relative to single mothers in the comparison group. The increase in employment rates seemed to take place through a rise in full time work, and it was driven by young, low-educated single mothers.

The results thus provide some evidence that benefit schedules that provide financial incentives to work may have significant effects on getting single mothers back to work, even when they have very young children. This result is relevant in the light of previous research, which has suggested that paid employment is associated with higher 
probabilities of exiting poverty. ${ }^{47}$ However, it should also be weighed against recent evidence pointing towards negative effects of early maternal employment of child outcomes. $^{48}$

${ }^{47}$ See van Leeuwen and Pannekoek (2002).

${ }^{48}$ See Ruhm (2004) and Gregg et al. (2005). 


\section{References}

Afsa, Cedric (1996) 'L'activité féminine a l'épreuve de l'allocation parentale d'éducation." Recherches et prévisions 46, pp. 1-8.

Algava, Elisabeth and Maria Avenel (2001) "Les bénéficiaires de l'Allocation de parent isole (API)“ DREES Etudes et Résultats n 112.

Cahuc, Pierre and André Zylberberg (2004) Labor Economics. MIT Press.

Card, David (1994) "Intertemporal Labor Supply: An Assessment." In Christopher Sims, editor, Advances in Econometrics, Sixth World Congress. New York: Cambridge University Press.

Conseil de l'Emploi, des Revenus et de la Cohésion sociale (2004), "Les Enfants Pauvres en France." Rapport N. 4. CERC : Paris.

Duncan, G. J. and J. Brooks-Gunn, eds. (1997), Consequences of Growing Up Poor. New York, Russel Sage.

Eissa, N., H.J. Kleven and C.T. Kreiner (2004), "Evaluation of Four Tax Reforms in the United States: Labor Supply and Welfare Effects for Single Mother", mimeo, Georgetown University.

Ermisch, John F. and Robert E. Wright (1991), "Welfare Benefits and Lone Parent's Employment in Great Britain", The Journal of Human Resources, 26, pp. 424-456.

Gonzalez, Libertad (2004), "Single Mothers and Work." Socio-Economic Review 2, pp. 285-313.

Gregg, Paul and Susan Harkness (2003), "Welfare Reform and Lone Parents' Employment in the UK”, CMPO Working Paper Series No. 03/072.

Gregg, Paul, Elizabeth Washbrook, Carol Propper and Simon Burgess (2005), "The effects of a mother's return to work decision on child development in the UK", Economic Journal 115, F48-F80.

Gurgand, Marc and David Margolis (2001) "RMI et revenus de travail : une évaluation des gains financier à l'emploi." Economie et statistique, N. 346-347.

Gurgand, Marc and David Margolis (2005) "Does Work Pay in France? Monetary Incentives and the Guaranteed Minimum Income." IZA Discussion Paper 1467.

Harvey, E. (1999), "Short-Term and Long-Term Effects of Early Parental Employment on Children of the National Longitudinal Survey of Youth." Developmental Psychology 35 , pp. 445-459.

Jenkins, Stephen J. (1992), "Lone Mother's Employment and Full-Time Work Probabilities", The Economic Journal, 102(411), pp. 310-320. 
Mayer, S. E. (1997), What Money Can't Buy: Family Income and Children's Life Chances, Cambridge, MA, Harvard University Press.

McLoyd, V. (1998), "Children in Poverty: Development, Public Policy, and Practice", in Handbook of Child Psychology, $4^{\text {th }}$ ed., ed. I. E. Siegel and K. A. Renninger, New York, Wiley.

Meyer, Bruce D. and Dan T. Rosenbaum (2000), "Making Single Mothers Work: Recent Tax and Welfare Policy and its Effects", National Tax Journal 53(4), pp. 10271062.

Meyer, Bruce D., and Dan T. Rosenbaum (2001), "Welfare, the Earned Income Tax Credit, and the Labor Supply of Single Mothers", Quarterly Journal of Economics 116, pp. 1063-1114.

Moore, K. A., M. Zaslow and A.K. Driscoll (1996), "Maternal Employment in LowIncome Families: Implications for Children's Development." Paper presented at meeting From Welfare to Work: Effects of Parents and Children, sponsored by the Packard Foundation and the American Academy of Arts and Sciences, Airlie Center, Virginia.

Piketty, Thomas (1998) "L'impact des incitations financières au travail sur les comportements individuels : une estimation pour le cas français" Économie et Prévision $\mathrm{n}^{\circ} 132-133$.

Piketty, Thomas (2002) 'L'impact de l'allocation parentale d'éducation sur l'activité féminine et la fécondité, 1982-2002.” Document de travail Cepremap 2003-09.

Ruhm, Christopher J. (2004) "Parental Employment and Child Cognitive Development." Journal of Human Resources 39(1), pp. 155-192.

Van Leeuwen, Jolanda and Jeroen Pannekoek (2002), "To Work Oneself out of Poverty: The Dutch Experience 1989-96"The Review of Income and Wealth, Vol. 48(1), pp. 127140.

Zaslow M. J. and C. A. Emig (1997), "When Low-Income Mothers Go to Work: Implications for Children." Future of Children 7, pp. 110-115. 
Figure 1. Activity and Employment Rates of Single Mothers, 1990-2002.

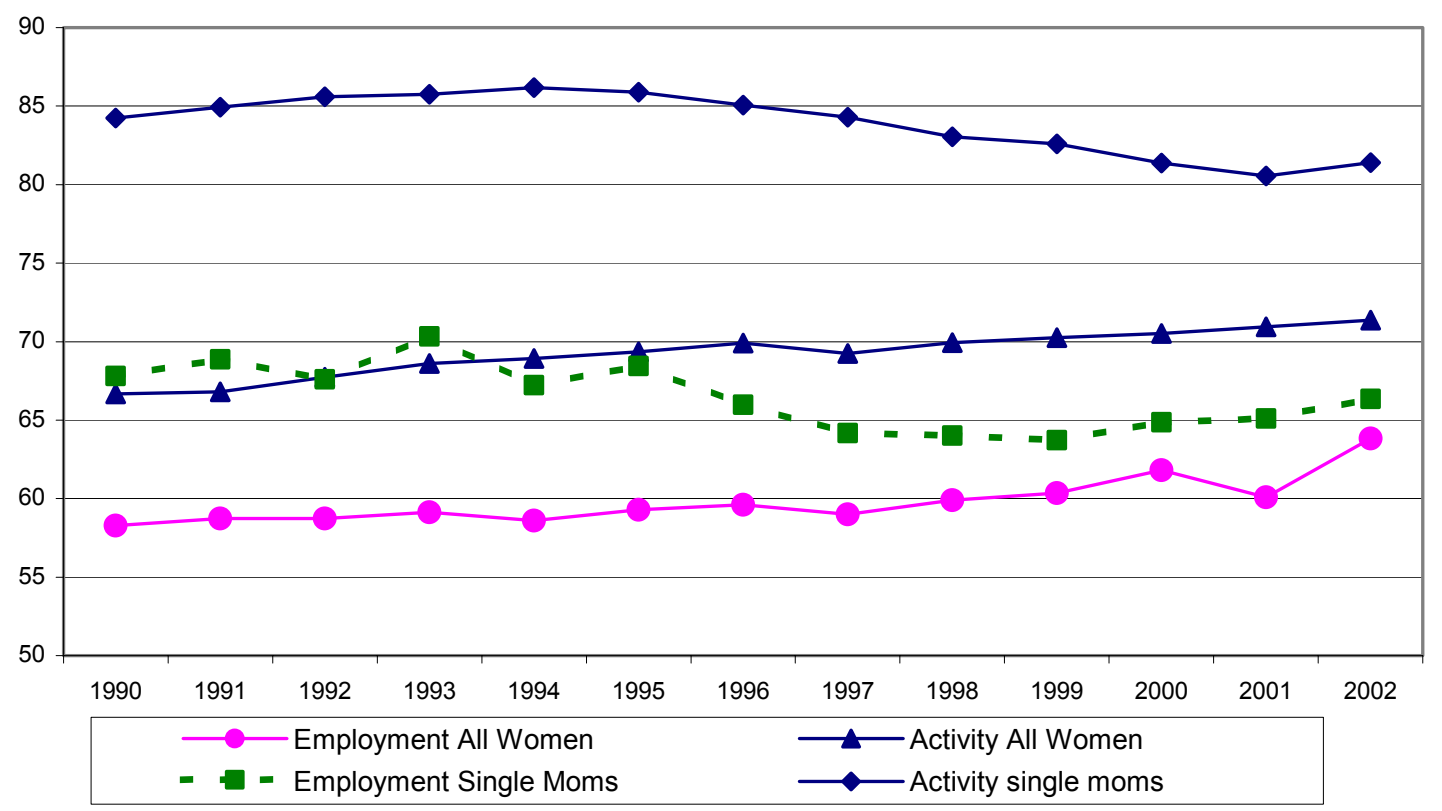

Notes: French Employment Survey data. Single mothers between 18 and 55 years old, with children under 18 years old. 
Table 1. Benefit Levels for Single Mothers Out of Paid Work in 1997

\begin{tabular}{crr}
\hline N. Children & API guarantee & RMI guarantee \\
\hline 1 & 4217 & 3605 \\
2 & 5271 & 4325 \\
3 & 6325 & 5287 \\
4 & 7379 & 6284 \\
5 & 8433 & 7209 \\
\hline
\end{tabular}

Note: Assuming no other income. In francs per month.

Table 2. Benefit Entitlement for Single Mothers with Children Under 3, Five Earnings Levels, in 1997 francs.

Table 2a) Before 1999.

\begin{tabular}{ccrrrr}
\hline N. Children & Wage $=3000$ & Wage $=5000$ & Wage $=6664$ & (SMIC) & Wage $=8000$ Wage $=10000$ \\
\hline 1 & 1217 & 0 & 0 & 0 & 0 \\
2 & 2271 & 675 & 675 & 675 & 675 \\
3 & 3325 & 1539 & 1539 & 1539 & 1539 \\
4 & 4379 & 2404 & 2404 & 2404 & 2404 \\
5 & 5433 & 3433 & 3268 & 3268 & 3268 \\
\hline
\end{tabular}

Table 2b) After 1999.

N. Children Wage $=3000$ Wage $=5000$ Wage $=6664($ SMIC) Wage $=8000$ Wage $=10000$

\begin{tabular}{llllll}
\hline 1 & 3467 & 2967 & 2551 & 2217 & 2109 \\
2 & 4521 & 4021 & 3605 & 3271 & 2973 \\
3 & 5575 & 5075 & 4659 & 4325 & 3932 \\
4 & 6629 & 6129 & 5713 & 5379 & 4892 \\
5 & 7683 & 7183 & 6767 & 6433 & 5933 \\
\hline
\end{tabular}

Note: Assuming no other income. In francs per month. The following benefits are take into account: API, RMI, universal family benefit, family supplement. 
Table 3. Benefit Entitlement for Single Mothers with No Children Under 3, Five Earnings Levels, in 1997 francs.

Table 3a) Before 1999.

\begin{tabular}{ccccrr}
\hline N.Children & Wage $=3000$ & Wage $=5000$ & Wage $=6664($ SMIC) & Wage $=8000$ & Wage $=10000$ \\
\hline 1 & 1230 & 460 & 114 & 0 & 0 \\
2 & 1950 & 1154 & 808 & 675 & 675 \\
3 & 2988 & 2571 & 2417 & 2417 & 2417 \\
4 & 3893 & 3476 & 3282 & 3282 & 3282 \\
5 & 4834 & 4381 & 4146 & 4146 & 4146 \\
\hline
\end{tabular}

Table 3b) After 1999.

\begin{tabular}{cccccr}
\hline N.Children & Wage $=3000$ & Wage $=5000$ & Wage $=6664($ SMIC) & Wage $=8000$ & Wage $=10000$ \\
\hline 1 & 2855 & 2355 & 1939 & 1803 & 1803 \\
2 & 3575 & 3075 & 2659 & 2500 & 2500 \\
3 & 4537 & 4037 & 3852 & 3852 & 3852 \\
4 & 5498 & 4998 & 4765 & 4765 & 4765 \\
5 & 6459 & 5959 & 5678 & 5678 & 5678 \\
\hline
\end{tabular}

Note: Assuming no other income and first year in employment. In francs per month. The following benefits are take into account: API, RMI, universal family benefit, family supplement.

Table 4. Increase in Benefits if Working After the Reform (first year of work, assuming earnings equal the minimum wage, monthly amounts, in 1997 francs)

\begin{tabular}{crrrr}
\hline N.Children & Children under 3 No Children under 3 & Difference & $\begin{array}{c}\text { Diff. Adjusted by } \\
\text { N. Children }\end{array}$ \\
\hline 1 & 2551 & 1825 & 726 & 726 \\
2 & 2930 & 1852 & 1079 & 763 \\
3 & 3120 & 1435 & 1685 & 973 \\
4 & 3309 & 1483 & 1826 & 913 \\
5 & 3499 & 1532 & 1967 & 880 \\
\hline
\end{tabular}

Note: Numbers calculated using the minimum wage as the earnings level. The last column is calculated as the "Difference" column divided by the square root of the number of children. 
Table 5. Descriptive Statistics, Treatment and Comparison Groups

\begin{tabular}{lcccccc}
\hline \multicolumn{2}{c}{$\begin{array}{l}\text { Treated single } \\
\text { mothers }\end{array}$} & \multicolumn{3}{c}{$\begin{array}{l}\text { Untreated single } \\
\text { mothers }\end{array}$} & Married mothers \\
\hline Employment & 0,369 & $(0,483)$ & 0,346 & $(0,476)$ & 0,542 & $(0,498)$ \\
Activity & 0,532 & $(0,499)$ & 0,567 & $(0,496)$ & 0,618 & $(0,486)$ \\
After $\left(d_{t}\right)$ & 0,900 & $(0,300)$ & 0,070 & $(0,255)$ & 0,479 & $(0,500)$ \\
Age & 31,2 & $(6,389)$ & 31,1 & $(6,251)$ & 31,7 & $(4,761)$ \\
Age sq. & 1013 & $(409)$ & 1006 & $(404)$ & 1027 & $(312)$ \\
Age cubed & 34188 & $(20506)$ & 33793 & $(20423)$ & 34020 & $(15808)$ \\
Years education & 13,4 & $(3,226)$ & 12,9 & $(3,026)$ & 14,2 & $(3,516)$ \\
Vocational deg. & 0,275 & $(0,447)$ & 0,274 & $(0,446)$ & 0,254 & $(0,435)$ \\
High school deg. & 0,231 & $(0,422)$ & 0,154 & $(0,361)$ & 0,338 & $(0,473)$ \\
Univ. Deg. & 0,056 & $(0,230)$ & 0,054 & $(0,225)$ & 0,133 & $(0,340)$ \\
One Child & 0,451 & $(0,498)$ & 0,450 & $(0,498)$ & 0,329 & $(0,470)$ \\
Two children & 0,285 & $(0,452)$ & 0,290 & $(0,454)$ & 0,365 & $(0,481)$ \\
Three children & 0,131 & $(0,338)$ & 0,138 & $(0,345)$ & 0,173 & $(0,379)$ \\
4+ Children & 0,080 & $(0,272)$ & 0,083 & $(0,275)$ & 0,079 & $(0,269)$ \\
Child<3 & 0,752 & $(0,432)$ & 0,707 & $(0,455)$ & 0,702 & $(0,457)$ \\
Child<6 & 0,910 & $(0,287)$ & 0,933 & $(0,250)$ & 0,920 & $(0,271)$ \\
Never married & 0,727 & $(0,446)$ & 0,648 & $(0,478)$ & 0,033 & $(0,178)$ \\
Widowed & 0,022 & $(0,146)$ & 0,026 & $(0,159)$ & 0,000 & $(0,020)$ \\
City & 0,483 & $(0,500)$ & 0,457 & $(0,498)$ & 0,367 & $(0,482)$ \\
N & & & & & & \\
\hline
\end{tabular}

Note: "Treated" single mothers are women aged 18 to 55 who were single mothers and had a child under the age of 3 at the time of at least one interview that took place after January 1999."Untreated" single mothers are women aged 18 to 55 who were single mothers and had a child under the age of 3 at the time of an interview that took place before January 1999, but not after January 1999. Married mothers included in the comparison group are women aged 18 to 55 who were married mothers with at least one child under the age of 3 at the time of one of the interviews (and did not qualify as a treated or untreated single mother in any of the interviews). Averages and standard errors (in parenthesis) are reported. 
Table 6. Probits for Employment and Activity, Single Mothers, 1995-2002.

\begin{tabular}{|c|c|c|c|c|c|c|c|c|}
\hline & \multicolumn{4}{|c|}{ Employment } & \multicolumn{4}{|c|}{ Activity } \\
\hline & 1 & & 2 & & 3 & & 4 & \\
\hline \multirow[t]{2}{*}{ Treated (dj) } & $-0,067$ & * & $-0,094$ & ** & $-0,070$ & * & $-0,075$ & * \\
\hline & $(0,040)$ & & $(0,044)$ & & $(0,041)$ & & $(0,045)$ & \\
\hline \multirow[t]{2}{*}{ After (dt) } & 0,015 & & 0,064 & & 0,064 & & 0,081 & \\
\hline & $(0,053)$ & & $(0,067)$ & & $(0,057)$ & & $(0,071)$ & \\
\hline \multirow[t]{2}{*}{ Treated, after (djdt) } & 0,058 & & 0,040 & & $-0,047$ & & $-0,052$ & \\
\hline & $(0,066)$ & & $(0,071)$ & & $(0,071)$ & & $(0,075)$ & \\
\hline \multirow[t]{2}{*}{ Age } & 0,293 & $* * *$ & 0,300 & $* * *$ & 0,274 & *** & 0,279 & $* * *$ \\
\hline & $(0,076)$ & & $(0,076)$ & & $(0,078)$ & & $(0,079)$ & \\
\hline \multirow[t]{2}{*}{ Age2 } & $-0,007$ & $* * *$ & $-0,008$ & $* * *$ & $-0,007$ & $\star \star \star *$ & $-0,007$ & $* * *$ \\
\hline & $(0,002)$ & & $(0,002)$ & & $(0,002)$ & & $(0,002)$ & \\
\hline \multirow[t]{2}{*}{ Years education } & 0,001 & & 0,001 & & $-0,005$ & & $-0,005$ & \\
\hline & $(0,004)$ & & $(0,004)$ & & $(0,004)$ & & $(0,004)$ & \\
\hline \multirow[t]{2}{*}{ Vocational training } & 0,160 & $* * *$ & 0,162 & $* * *$ & 0,122 & $* * *$ & 0,122 & $* * *$ \\
\hline & $(0,023)$ & & $(0,023)$ & & $(0,022)$ & & $(0,022)$ & \\
\hline \multirow[t]{2}{*}{ High school diploma } & 0,349 & $* * *$ & 0,351 & $* * *$ & 0,268 & $* * *$ & 0,268 & $* * *$ \\
\hline & $(0,029)$ & & $(0,029)$ & & $(0,025)$ & & $(0,025)$ & \\
\hline \multirow[t]{2}{*}{ University diploma } & 0,401 & $* * *$ & 0,399 & $* * *$ & 0,355 & *** & 0,354 & $* * *$ \\
\hline & $(0,047)$ & & $(0,047)$ & & $(0,030)$ & & $(0,030)$ & \\
\hline \multirow[t]{2}{*}{1 child } & $-0,030$ & & $-0,029$ & & 0,066 & & 0,065 & \\
\hline & $(0,058)$ & & $(0,058)$ & & $(0,069)$ & & $(0,069)$ & \\
\hline \multirow[t]{2}{*}{2 children } & $-0,185$ & $* * *$ & $-0,186$ & $* * *$ & $-0,130$ & * & $-0,132$ & * \\
\hline & $(0,052)$ & & $(0,052)$ & & $(0,071)$ & & $(0,071)$ & \\
\hline \multirow[t]{2}{*}{3 children } & $-0,235$ & $* * *$ & $-0,236$ & $* * *$ & $-0,221$ & $* * *$ & $-0,222$ & $* * *$ \\
\hline & $(0,042)$ & & $(0,042)$ & & $(0,072)$ & & $(0,072)$ & \\
\hline \multirow[t]{2}{*}{ More than 3 children } & $-0,323$ & $* * *$ & $-0,324$ & $* * *$ & $-0,396$ & $* * *$ & $-0,398$ & $* * *$ \\
\hline & $(0,023)$ & & $(0,023)$ & & $(0,058)$ & & $(0,058)$ & \\
\hline \multirow[t]{2}{*}{1 child $<3$} & $-0,078$ & $* * *$ & $-0,071$ & $* * *$ & $-0,105$ & $* * *$ & $-0,108$ & *** \\
\hline & $(0,024)$ & & $(0,025)$ & & $(0,025)$ & & $(0,025)$ & \\
\hline \multirow[t]{2}{*}{ More than 1 child $<3$} & $-0,118$ & ** & $-0,113$ & * & $-0,195$ & *** & $-0,200$ & $* * *$ \\
\hline & $(0,057)$ & & $(0,058)$ & & $(0,061)$ & & $(0,061)$ & \\
\hline \multirow[t]{2}{*}{1 child $<6$} & $-0,045$ & & $-0,064$ & & $-0,073$ & & $-0,073$ & \\
\hline & $(0,050)$ & & $(0,051)$ & & $(0,056)$ & & $(0,057)$ & \\
\hline \multirow[t]{2}{*}{2 children $<6$} & $-0,084$ & & $-0,100$ & * & $-0,125$ & $* *$ & $-0,126$ & ** \\
\hline & $(0,052)$ & & $(0,051)$ & & $(0,063)$ & & $(0,064)$ & \\
\hline \multirow[t]{2}{*}{ More than 2 children $<6$} & $-0,142$ & * & $-0,153$ & ** & $-0,071$ & & $-0,069$ & \\
\hline & $(0,079)$ & & $(0,077)$ & & $(0,093)$ & & $(0,094)$ & \\
\hline \multirow[t]{2}{*}{ City $>200,000$} & 0,034 & $* *$ & 0,036 & $* *$ & 0,052 & $* * *$ & 0,052 & $* * *$ \\
\hline & $(0,017)$ & & $(0,017)$ & & $(0,018)$ & & $(0,018)$ & \\
\hline \multirow[t]{2}{*}{ Never married } & $-0,038$ & * & $-0,039$ & * & $-0,037$ & * & $-0,037$ & * \\
\hline & $(0,021)$ & & $(0,021)$ & & $(0,022)$ & & $(0,022)$ & \\
\hline Widowed & 0,012 & & 0,012 & & $-0,012$ & & $-0,013$ & \\
\hline & $(0,058)$ & & $(0,058)$ & & $(0,061)$ & & $(0,062)$ & \\
\hline Year dummies? & $\mathrm{N}$ & & Y & & $\mathrm{N}$ & & Y & \\
\hline
\end{tabular}

Note: The sample includes "treated" and "untreated" single mothers, i.e., all women aged 18 to 55 who were single mothers and had a child under the age of 3 in at least on of the three interviews (Enquete Emploi 1995-2002). Sample size is 3,515. Marginal effects are shown. Standard errors are in parenthesis. One asterisk indicates that a variable is significant at the $90 \%$ level, two indicate significance at the 95\% level, and three, at the 99\% level. Age cubed, although not reported, is also included in the regressions and always significant. 
Table 7. Probits for Employment and Activity, 1995-2002.

\begin{tabular}{|c|c|c|c|c|c|c|c|c|}
\hline & \multicolumn{4}{|c|}{ Employment } & \multicolumn{4}{|c|}{ Activity } \\
\hline & 1 & & 2 & & 3 & & 4 & \\
\hline \multirow[t]{2}{*}{ Treated $(\mathrm{j}=2)$} & $-0,076$ & * & $-0,061$ & & $-0,083$ & $* *$ & $-0,062$ & \\
\hline & $(0,043)$ & & $(0,043)$ & & $(0,041)$ & & $(0,041)$ & \\
\hline \multirow[t]{2}{*}{ Single mothers $(j=1)$} & $-0,145$ & $* * *$ & $-0,146$ & $* * *$ & $-0,001$ & & $-0,001$ & \\
\hline & $(0,015)$ & & $(0,015)$ & & $(0,014)$ & & $(0,014)$ & \\
\hline \multirow[t]{2}{*}{ After (dt) } & $-0,019$ & $* * *$ & $-0,012$ & & $-0,026$ & $* * *$ & $-0,023$ & ** \\
\hline & $(0,006)$ & & $(0,011)$ & & $(0,006)$ & & $(0,011)$ & \\
\hline \multirow[t]{2}{*}{ Single mothers, after $\left.\left(d_{(j=1)}\right) d t\right)$} & 0,046 & & 0,046 & & 0,099 & $* *$ & 0,089 & * \\
\hline & $(0,055)$ & & $(0,055)$ & & $(0,046)$ & & $(0,047)$ & \\
\hline \multirow[t]{2}{*}{ Treated, after $\left.\left(d_{\mathrm{j}}=2\right) \mathrm{dt}\right)$} & 0,057 & & 0,043 & & $-0,052$ & & $-0,059$ & \\
\hline & $(0,069)$ & & $(0,069)$ & & $(0,041)$ & & $(0,068)$ & \\
\hline \multirow[t]{2}{*}{ Age } & 0,297 & $* * *$ & 0,296 & $* * *$ & 0,190 & $* * *$ & 0,189 & *** \\
\hline & $(0,034)$ & & $(0,034)$ & & $(0,030)$ & & $(0,030)$ & \\
\hline \multirow[t]{2}{*}{ Age2 } & $-0,007$ & $* * *$ & $-0,007$ & $* * *$ & $-0,004$ & $* \star *$ & $-0,004$ & $* * *$ \\
\hline & $(0,001)$ & & $(0,001)$ & & $(0,001)$ & & $(0,001)$ & \\
\hline \multirow[t]{2}{*}{ Years of education } & 0,010 & $* * *$ & $(0,010)$ & $* * *$ & 0,009 & $* * *$ & 0,009 & $* * *$ \\
\hline & $(0,001)$ & & $(0,001)$ & & $(0,001)$ & & $(0,001)$ & \\
\hline \multirow[t]{2}{*}{ Vocational training } & 0,147 & $* * *$ & 0,147 & $* * *$ & 0,111 & $* * *$ & 0,111 & *** \\
\hline & $(0,007)$ & & $(0,007)$ & & $(0,007)$ & & $(0,007)$ & \\
\hline \multirow[t]{2}{*}{ High school diploma } & 0,272 & $* * *$ & 0,272 & $* * *$ & 0,219 & $* * *$ & 0,219 & $* * *$ \\
\hline & $(0,008)$ & & $(0,008)$ & & $(0,008)$ & & $(0,008)$ & \\
\hline \multirow[t]{2}{*}{ University diploma } & 0,296 & $* * *$ & 0,296 & $* * *$ & 0,240 & $* * *$ & 0,240 & $* * *$ \\
\hline & $(0,010)$ & & $(0,010)$ & & $(0,009)$ & & $(0,009)$ & \\
\hline \multirow[t]{2}{*}{1 child } & $-0,045$ & $* *$ & $-0,044$ & $* *$ & 0,008 & & 0,008 & \\
\hline & $(0,022)$ & & $(0,022)$ & & $(0,022)$ & & $(0,022)$ & \\
\hline \multirow[t]{2}{*}{2 children } & $-0,213$ & $* * *$ & $-0,212$ & $* \star *$ & $-0,199$ & $* * *$ & $-0,198$ & $* * *$ \\
\hline & $(0,021)$ & & $(0,021)$ & & $(0,021)$ & & $(0,022)$ & \\
\hline \multirow[t]{2}{*}{3 children } & $-0,362$ & $* * *$ & $-0,361$ & $* * *$ & $-0,374$ & $* * *$ & $-0,373$ & *** \\
\hline & $(0,018)$ & & $(0,018)$ & & $(0,022)$ & & $(0,022)$ & \\
\hline \multirow[t]{2}{*}{ More than 3 children } & $-0,468$ & $* * *$ & $-0,467$ & $* * *$ & $-0,499$ & $* * *$ & $-0,498$ & $* * *$ \\
\hline & $(0,012)$ & & $(0,012)$ & & $(0,019)$ & & $(0,019)$ & \\
\hline \multirow[t]{2}{*}{1 child $<3$} & $-0,060$ & $* * *$ & $-0,063$ & $* * *$ & $-0,078$ & $* * *$ & $-0,082$ & *** \\
\hline & $(0,007)$ & & $(0,007)$ & & $(0,007)$ & & $(0,007)$ & \\
\hline \multirow[t]{2}{*}{ More than 1 child $<3$} & $-0,080$ & $* * *$ & $-0,083$ & $* * *$ & $-0,119$ & $* \star \star$ & $-0,123$ & *** \\
\hline & $(0,018)$ & & $(0,018)$ & & $(0,018)$ & & $(0,018)$ & \\
\hline \multirow[t]{2}{*}{1 child $<6$} & $-0,045$ & $\star *$ & $-0,041$ & $* *$ & $-0,043$ & $* *$ & $-0,037$ & ** \\
\hline & $(0,018)$ & & $(0,018)$ & & $(0,017)$ & & $(0,018)$ & \\
\hline \multirow[t]{2}{*}{2 children $<6$} & $-0,109$ & $* * *$ & $-0,105$ & $* * *$ & $-0,111$ & $* * *$ & $-0,106$ & $* * *$ \\
\hline & $(0,019)$ & & $(0,019)$ & & $(0,020)$ & & $(0,020)$ & \\
\hline \multirow[t]{2}{*}{ More than 2 children $<6$} & $-0,147$ & $* * *$ & $-0,145$ & $* * *$ & $-0,124$ & $* * *$ & $-0,120$ & *** \\
\hline & $(0,027)$ & & $(0,027)$ & & $(0,028)$ & & $(0,028)$ & \\
\hline City $>200,000$ & $-0,028$ & $* * *$ & $-0,028$ & $* \star *$ & $-0,023$ & $* * *$ & $-0,023$ & $* * *$ \\
\hline & $(0,006)$ & & $(0,006)$ & & $(0,006)$ & & $(0,006)$ & \\
\hline Year dummies? & $\mathrm{N}$ & & $Y$ & & $\mathrm{~N}$ & & $Y$ & \\
\hline
\end{tabular}

Note: The sample includes "treated" and "untreated" single mothers (i.e., all women aged 18 to 55 who were single mothers and had a child under the age of 3 in at least on of the three interviews), as well as married mothers who had a child under the age of 3 in at least one of the interviews (Enquete Emploi 1995-2002). Sample size is 39,533. Marginal effects are shown. Standard errors are in parenthesis. One asterisk indicates that a variable is significant at the $90 \%$ level, two indicate significance at the 95\% level, and three, at the 99\% level. Age cubed, although not reported, is also included in the regressions and always significant. 
Table 8. Probits for Employment by Education Level, 1995-2002.

\begin{tabular}{|c|c|c|c|c|c|c|}
\hline & No univ. Educ. & & No hs deg. & & Hs deg. & \\
\hline \multirow[t]{2}{*}{ Treated $(\mathrm{j}=2)$} & $-0,069$ & & $-0,052$ & & $-0,064$ & \\
\hline & $(0,044)$ & & $(0,046)$ & & $(0,078)$ & \\
\hline \multirow[t]{2}{*}{ Single mothers $(j=1)$} & $-0,148$ & $\star \star * *$ & $-0,152$ & $* \star \star$ & $-0,083$ & *** \\
\hline & $(0,015)$ & & $(0,014)$ & & $(0,029)$ & \\
\hline \multirow[t]{2}{*}{ After (dt) } & $-0,014$ & & $-0,018$ & & $-0,011$ & \\
\hline & $(0,012)$ & & $(0,152)$ & & $(0,014)$ & \\
\hline \multirow[t]{2}{*}{ Single mothers, after $\left(d_{(j=1)} d t\right)$} & 0,043 & & 0,014 & & 0,247 & ** \\
\hline & $(0,057)$ & & $(0,059)$ & & $(0,060)$ & \\
\hline \multirow[t]{2}{*}{ Treated, after $\left(\mathrm{d}_{(\mathrm{j}=2) \mathrm{dt})}\right.$} & 0,054 & & 0,074 & & $-0,325$ & \\
\hline & $(0,071)$ & & $(0,079)$ & & $(0,210)$ & \\
\hline $\mathrm{N}$ & 34533 & & 21657 & & 17876 & \\
\hline
\end{tabular}

Note: The sample includes "treated" and "untreated" single mothers (i.e., all women aged 18 to 55 who were single mothers and had a child under the age of 3 in at least on of the three interviews), as well as married mothers who had a child under the age of 3 in at least one of the interviews (Enquete Emploi 1995-2002). Marginal effects are shown. Standard errors are in parenthesis. One asterisk indicates that a variable is significant at the $90 \%$ level, two indicate significance at the $95 \%$ level, and three, at the $99 \%$ level. Controls include age, age squared, age cubed, dummies for number of children, child(ren) under 3 and under 6 , a dummy for cities of more than 200,000 inhabs., number of years of education, and a dummy for vocational training. 